\title{
IMPROVE WATER SAVING AND WATER PRODUCTIVITY BY NEW APPROACH OF FARM MANAGEMENT UNDER SURFACE IRRIGATION
}

\section{Atef Swelam ${ }^{1}$ and Yousri Atta ${ }^{2}$}

\begin{abstract}
Two field experiments were conducted during summer seasons of 2007 and 2008 at Zankalon Water Research Station, Water Management and Irrigation Systems Research Institute, Egypt. This research aims to study the effect of new approach of farm layout and management under surface irrigation on water saving and yield of corn. Three irrigation and planting treatments were investigated, treatment A used traditional irrigation method (control treatment) with $80 \mathrm{~cm}$ width furrows and one row of plants on each ridge with one plant/hill and $22 \mathrm{~cm}$ between hills. Treatment $B$ had $80 \mathrm{~cm}$ wide furrows with one row planted in the bottom of each furrow with one plant/hill and $22 \mathrm{~cm}$ between hills. Treatment $C$ had $160 \mathrm{~cm}$ wide furrows with two rows planted in the bottom of each furrow with one plant/hill and $22 \mathrm{~cm}$ between hills. Comparisons were based on the growth, yield, yield attributes, water relations, and the net return of the corn crop (cultivar T.W.C310). Comparing to the traditional practice (treatment $A)$ water saving from using treatments $B$ and $C$ were $2467 \mathrm{~m}^{3} \mathrm{ha}^{-1}(30.3 \%)$ and $4333 \mathrm{~m}^{3} \mathrm{ha}^{-1}$ (53.2\%), respectively. Actual evapotranspiration values for treatments $A, B$ and $C$ were 553,410 and $293 \mathrm{~mm}$ respectively. The values of water productivity $\left(\mathrm{kg} \mathrm{m}^{-3}\right)$ were 0.74 , 1.13 and 1.73 for $A, B$ and $C$ treatments, respectively. The lowest irrigation cost was observed for method $C$ and the net profit increased by $19 \%$ using treatment $B$ and $32 \%$ using treatment $C$. Significant increase in grain yield was achieved, $6 \%$ and $9 \%$ for the $B$ and $C$ treatments, respectively.
\end{abstract}

Keywords: In-furrow planting, Water saving, Surface irrigation, Water productivity, Maize, Corn

\footnotetext{
1. Nile Valley and Sub-Saharan Africa Regional Program, ICARDA, Egypt, a.swelam@cgiar.org

2. Water Management and Irrigation Systems Research Institute, National Water Research Center, Egypt
} 


\section{INTRODUCTION}

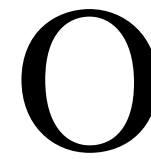
ne of the main objectives of the Egyptian Sustainable Agricultural Development Strategy towards 2030 is to expand the cultivated area by reclaiming and cultivating additional land and finding alternative renewable water resources in new regions. The vertical expansion aims to increases crop productivity per unit of water use, and to improve on-farm irrigation efficiency. Recent studies indicate that, by year 2025, severe water scarcity will affect one-third of the population in developing countries, and there will be insufficient water resources to cover agricultural, domestic, industrial and environmental needs. One method to alleviate water scarcity is to reduce evapotranspiration loss in irrigated agriculture. Better irrigation scheduling and controlling application amounts can lead to more productive water use without additional costs to farmers. As population in Egypt continues to increase, demands for water including irrigation will also increase. Therefore, on-farm irrigation planners and water resource mangers will continue to study system and management alternatives to evaluate their impacts on water supplies in watersheds.

Surface irrigation is the traditional irrigation method (about $80 \%$ of the irrigated area in Egypt), and it generally has lower application efficiency (about 50\%) than other methods mainly because of water loss to deep percolation, which lead to rising ground water tables and leaching of nutrients. Consequently, deep percolation has a negative effect on crop yield, fertilizer requirements, and efficient water use (Donahue et al. 1977). Farmers commonly over-irrigate their fields, so losses of water are often appreciable. Therefore, optimal irrigation application, throughout the growing season, is important for increasing corn productivity per unit of water applied without additional costs.

Maize is the world's third most important crop after rice and wheat. About half of the maize production comes from developing countries. Maize is grown during summer in Egypt, it is an important cereal crop for human consumption, animal feed, and industrial purposes (e.g., for oil and starch production). The production of corn in Egypt is insufficient to match the local consumption, so there is a need to expand the cultivated 
area. This, however, will require more irrigation water unless improved management can extend the limited water resource over a larger area.

Large water savings (up to 50\%), using alternate furrow irrigation (AFI), without a loss in yield have been achieved in the USA with substantial reductions in the labour required to carry out the irrigation (Stone and Nofziger, 1993; Mitchell et al, 1995). According to Kemper et al. (1975) irrigation by flooding water over the entire field results in leaching down the nitrates from the root zone causing loss of fertilizer. Over irrigation often leads to greater leaching loss of fertilizer and thereby reduces the final plant height, dry matter accumulation and grain yield of maize (Mahal et al., 2000). The application of irrigation water in every furrow irrigation (EFI) gave higher grain yield of maize than alternate furrow irrigation (Selvaraju and Iruthayaraj, 1993). Fischbach and Mulliner (1974) obtained similar corn yield with alternate-furrow and every-furrow irrigation.

Ahmad, et al, (2002) studied the effect of different irrigation methods on irrigated maize and found that, the every-furrow method produced significantly higher grain yield $\left(7.38 \mathrm{t} \mathrm{ha}^{-1}\right)$ than alternate-furrow method which gave $\left(3.59 \mathrm{t}^{-\mathrm{ha}^{-1}}\right.$ ). If alternate-furrow irrigation (AFI) is applied without allowing for a reduced irrigation water deficit, substantial yield loss may occur. However, where a smaller deficit is maintained by using AFI, water saving is reduced but yield is maintained. This shows that water productivity is increased by using AFI and the method can lead to substantial benefits under limited water conditions (Bakker, et al, 1997).

Kanga, et al, (2000) developed a new irrigation method to improve yield and water productivity of maize. The field experiment was conducted in an arid area, with seasonal rainfall of $80 \mathrm{~mm}$, over 2 years. Irrigation was applied through furrows in three ways: alternate furrow irrigation (AFI), fixed furrow irrigation (FFI), and every furrow irrigation (EFI). The AFI method maintained high grain yield with up to $50 \%$ reduction in irrigation water applied, while FFI and EFI all showed a substantial decreases in yield with reduced irrigation, as a result, water productivity was substantially increased. 
Mintesinot, et al (2004) conducted a comparative study between the traditional irrigation management (every furrow-traditional scheduling) and alternative water management options on maize plots in northern Ethiopia. They found that the yield and economic productivity-based comparison has shown that every furrow-scientific scheduling generates the highest yield levels followed by alternate furrows-scientific scheduling. The yield increase (by every furrow-scientific scheduling) over the traditional management was found to be $54 \%$, while the water productivity based comparisons have shown that alternate furrowsscientific scheduling generates the highest water productivity values followed by every furrow-scientific scheduling.

The strategy of irrigation policy in Egypt aims to optimizing water use by better management, accurate estimation of crop water requirements and irrigation scheduling. This paper introduces a new approach of farm layouts for surface irrigation for higher water productivity and high potential for water saving.

\section{MATERIALS AND METHODS}

\section{Location and Timing}

This investigation was conducted during 2007 and 2008 seasons at Zankalon Water Research Station, Water Management and Irrigation Systems Research Institute, Egypt which is located in the East Nile Delta region. The site is located at $30^{\circ} 35^{\prime} \mathrm{N}$. latitude and $31^{\circ} 30^{\prime} \mathrm{E}$. longitude with an elevation of about $9 \mathrm{~m}$ above msl. The experimental plot soil is mostly clay, and samples were collected to determine some soil physical and chemical properties (Table 1).

Table (1): Some oil physical and chemical properties of the experimental site

\begin{tabular}{|c|c|c|c|c|c|c|c|c|c|c|}
\hline $\begin{array}{l}\text { Depth } \\
(\mathrm{cm})\end{array}$ & $\begin{array}{c}\text { Sand } \\
\%\end{array}$ & $\begin{array}{l}\text { Silt } \\
\%\end{array}$ & $\begin{array}{c}\text { Clay } \\
\%\end{array}$ & 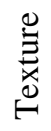 & $\begin{array}{l}\text { Bulk density } \\
\qquad\left(\mathrm{g} \mathrm{cm}^{-3}\right)\end{array}$ & $\begin{array}{c}\text { Field } \\
\text { capacity } \\
(\%)\end{array}$ & $\begin{array}{c}\text { Wilting } \\
\text { point } \\
(\%)\end{array}$ & $\begin{array}{c}\text { Available } \\
\text { water } \\
(\%)\end{array}$ & 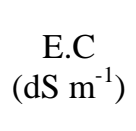 & $\mathrm{pH}$ \\
\hline $0-15$ & 25.80 & 29.69 & 44.51 & \multirow{5}{*}{$\frac{\vec{\Xi}}{U}$} & 1.25 & 43.51 & 23.55 & 19.96 & 1.40 & 8.1 \\
\hline $15-30$ & 25.12 & 31.38 & 43.50 & & 1.27 & 40.50 & 21.06 & 19.44 & 1.22 & 8.0 \\
\hline $30-45$ & 26.00 & 32.20 & 41.80 & & 1.35 & 37.12 & 17.59 & 19.53 & 1.25 & 8.0 \\
\hline $45-60$ & 26.70 & 33.00 & 40.30 & & 1.41 & 36.27 & 16.64 & 19.64 & 1.05 & 8.0 \\
\hline Average & 25.91 & 31.57 & 42.50 & & 1.32 & 39.35 & 19.71 & 19.64 & 1.23 & 8.03 \\
\hline
\end{tabular}


Seeds of T.W.C 310 maize cultivar were planted at a population density of 57143 plants per hectare on 1 June 2006 and 5 June 2007. Fertilizer (calcium superphosphate $15.5 \% \mathrm{P}_{2} \mathrm{O}_{5}$ with rate of $240 \mathrm{~kg} \mathrm{ha}^{-1}$ during land preparation and nitrogen fertilizer as urea $(46 \% \mathrm{~N})$ was applied at a rate of $286 \mathrm{~kg} \mathrm{ha}^{-1}$ in two equal doses before the first and the second irrigations. After full germination and before the first irrigation, the plants were thinned to attain the recommended plant density (57143 pl/ha). All other cultural practices for growing corn were similar to the local growers. Harvest dates were 5 and 8 October in both seasons, respectively.

\section{Farm Management Methods}

In Treatment A, the traditional method, rows were planted $0.80 \mathrm{~m}$ apart with one row of plants on each ridge between furrows with one plant/hill and $0.22 \mathrm{~m}$ between plants within the rows to attain recommended plant density, 57143 plants per hectare, (Fig. 1). The plots were approximately $20 \mathrm{~m}$ long; the furrows were about $0.20 \mathrm{~m}$ deep, with closed ends to prevent runoff from the field. When water was applied to treatment $A$, the application was stopped when the water level in the furrows approached the top of the furrow ridge, which is similar to the typical farmer practice in the region.

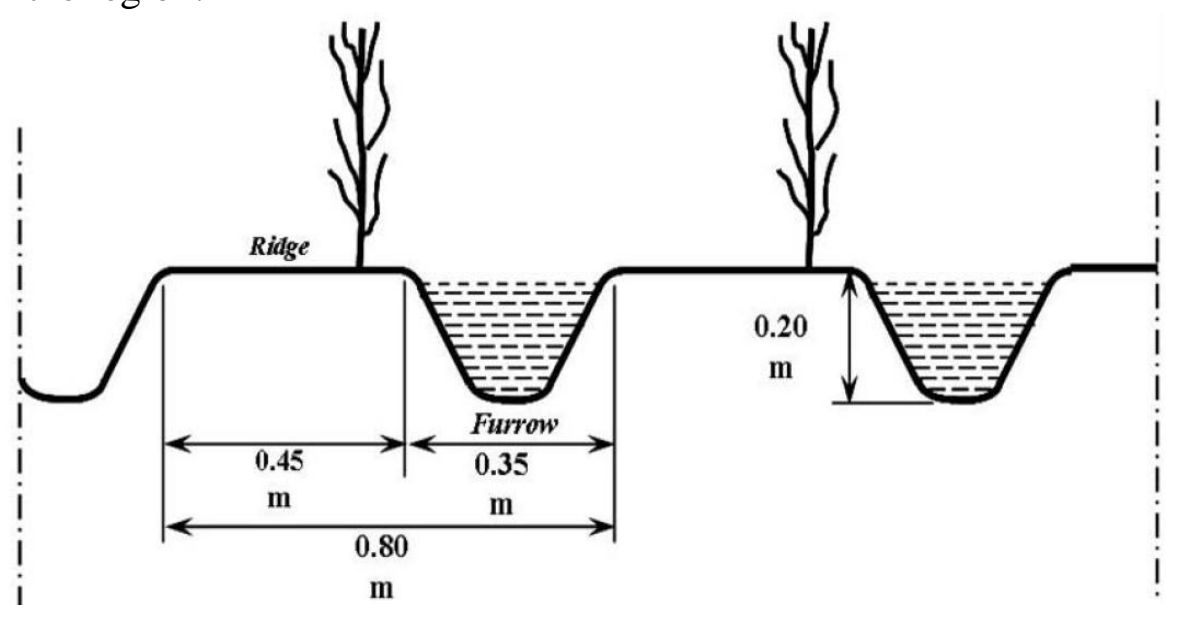

Figure (1): Diagram of the method A planting, where plants were seeded with a $0.80 \mathrm{~m}$ row spacing with one row of plants near the edge of a ridge and $0.22 \mathrm{~m}$ between plants within rows; giving 57140 plants per ha. 
The new farm management treatments were planned to decrease the wetted area and to reduce the need for long irrigation time to sub-up water from the furrows to the ridges of the borders. For treatment $\mathrm{B}$, the same plant distance $(0.80 \mathrm{~m} \times 0.22 \mathrm{~m})$ was used to maintain the plant density as in the traditional method except that one row of corn was planted in the bottom of each furrow (Fig. 2). The irrigation frequency was similar to the local farming practices.

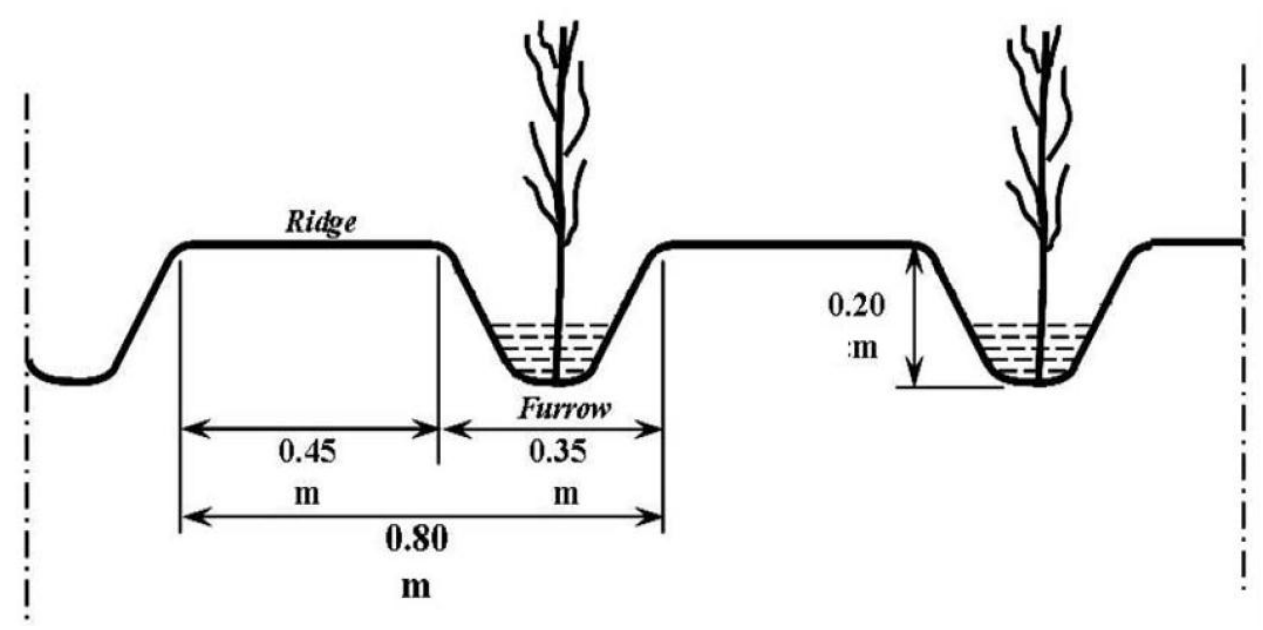

Figure (2): Diagram of the method B planting, where plants were seeded at $0.80 \mathrm{~m}$ row spacing with one row of plants in the middle of the furrow and $0.22 \mathrm{~m}$ between plants within rows; giving 57140 plants per ha.

In treatment $\mathrm{B}$, irrigation was applied until the water in the furrows reached the far end of the furrows, which was blocked to prevent runoff. The furrow length in all treatments was similar to traditional practices which is short furrows $(10 \mathrm{~m})$ so that run time, water advancing rate and land furrow slop were negligible factors. Thus, the difference in water applied between treatments A and B is mainly due to the water depth in the furrow, Table (2), since water was applied to treatment A until the water level in the furrows nearly reached the ridge. This was needed to insure that water would sub-up to the ridge tops where the plants were growing it means that water depth in the furrow was at the maximum level $(15 \mathrm{~cm})$. This was unnecessary in treatment $\mathrm{B}$ because the plants 
were planted in the bottoms of the furrows and water depth was at the middle of furrows capacity $(10 \mathrm{~cm})$.

Treatment $\mathrm{C}$ had a furrow spacing of $1.60 \mathrm{~m}$, which is double that of treatments $\mathrm{A}$ and $\mathrm{B}$, but there were two rows of corn planted in the bottom of each furrow (Fig. 3) with $0.22 \mathrm{~m}$ between plants, so the plant density was the same in all three treatments. Like treatment B, water was applied to the furrows in treatment $\mathrm{C}$ until the water reached the end of the furrows, which were blocked to prevent runoff. Because the furrow wetted area in treatment $\mathrm{C}$ was half of that in treatment $\mathrm{B}$, considerably less water was applied to the same plant density.

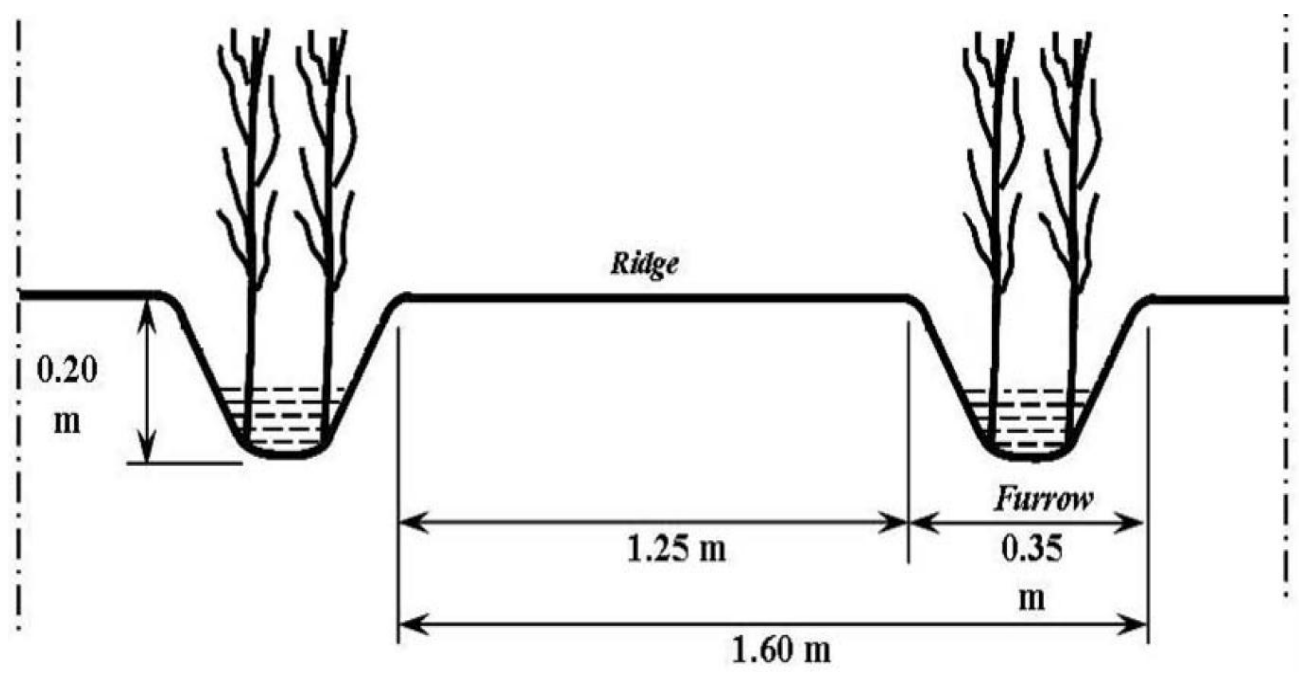

Figure (3): Diagram of the method C planting, where furrows were spaced at $1.60 \mathrm{~m}$ with two rows of plants seeded near the edges of the bottom of each furrow and $0.11 \mathrm{~m}$ between plants within rows; giving 57140 plants per ha.

The three treatments were arranged in a complete randomized block design with four replicates. The area of each plot was $320 \mathrm{~m}^{2}$ (20 m long $\mathrm{x} 16 \mathrm{~m}$ wide) with a border of $1.5 \mathrm{~m}$ between them to avoid lateral seepage. Collected data were statistical analyzed by year and the two seasons combined using the method adopted by Steel and Torrie (1980). The treatments means were compared using the least significant differences (L.S.D) method. 


\section{Applied Water $\left(A_{W}\right)$}

The irrigation water used for the experiments had the typical water quality for the region with $\mathrm{EC}$ of $0.4 \mathrm{dS} / \mathrm{m}$. Applied water $\left(A_{W}\right)$ was measured using a calibrated flowmeter with reading resolution of 5 decimals of $\mathrm{m}^{3}$. Irrigation water was transferred to each plot through $0.15 \mathrm{~m}$ diameter polyethylene pipes, and the applications were controlled using a valve at the front of each plot. All treatment plots received exactly 7 irrigation events including the sowing watering. For the first irrigation, an equal amount of water was applied to all treatments until puddling occurred. The irrigation was managed to avoid leaving water puddles on the surface for more than 10 hours. As agronomical recommendation, the second irrigation occurred 21 days after planting (dap), and subsequent irrigation were applied at 14 day intervals. Irrigation was stopped at 105 dap (2006) and 110 dap (2007). The two year means of applied water are given by treatment in Table (2).

Table (2): Effect of irrigation methods on irrigation duration, applied water, water saved, actual evapotranspiration, grain yield and water productivity.

\begin{tabular}{|c|c|c|c|c|c|c|c|c|}
\hline \multirow{2}{*}{ 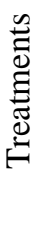 } & \multirow{2}{*}{$\begin{array}{l}\text { Applied } \\
\text { water } \\
\left(A_{W}\right) \\
(\mathrm{mm})\end{array}$} & \multirow{2}{*}{$\begin{array}{c}\text { Actual } \\
\text { evapotranspiration } \\
\left(E T_{C}\right) \\
(\mathrm{mm})\end{array}$} & \multicolumn{2}{|c|}{ Water saved } & \multicolumn{2}{|c|}{ Grain yield } & \multicolumn{2}{|c|}{$\begin{array}{l}\text { Water productivity } \\
\qquad\left(W_{P}\right)\end{array}$} \\
\hline & & & $(\mathrm{mm})$ & $(\%)$ & $\left(\right.$ ton $\left.\mathrm{ha}^{-1}\right)$ & $(\%)$ & $\left(\mathrm{kg} \mathrm{m}^{-3}\right)$ & $(\%)$ \\
\hline A & 814.3 & 553 & - & - & $6.067 \mathrm{a}$ & - & 0.74 & - \\
\hline B & 567.6 & 410 & 246.7 & 30.3 & $6.400 \mathrm{~b}$ & 6 & 1.13 & 52.7 \\
\hline $\mathrm{C}$ & 381.0 & 293 & 433.3 & 53.2 & $6.600 \mathrm{c}$ & 9 & 1.73 & 133.8 \\
\hline
\end{tabular}

\section{Reference evapotranspiration (ETo):}

Reference evapotranspiration (ETo), was estimated from daily weather data using a modified version of the Penman-Monteith equation (Allen et al., 1998):

$$
E T_{o}=\frac{0.408 \Delta\left(R_{n}-G\right)+\gamma \frac{900}{T+273} u_{2}\left(e_{s}-e_{a}\right)}{\Delta+\gamma\left(1+0.34 u_{2}\right)}
$$


Where $\Delta\left(\mathrm{kPa}^{\circ} \mathrm{C}^{-1}\right)$ is the slope of the saturation vapor pressure curve at mean air temperature, $\mathrm{Rn}$ and $\mathrm{G}$ are the net radiation and soil heat flux density in $\mathrm{MJ} \mathrm{m}{ }^{-2} \mathrm{~d}^{-1}, \gamma\left(\mathrm{kPa}{ }^{\circ} \mathrm{C}^{-1}\right)$ is the psychrometric constant, $\mathrm{T}\left({ }^{\circ} \mathrm{C}\right)$ is the daily mean temperature, $\mathrm{U} 2\left(\mathrm{~m} \mathrm{~s}^{-1}\right)$ is the mean wind speed, es $(\mathrm{kPa})$ is the saturation vapor pressure calculated from $\mathrm{T}$, and ea $(\mathrm{kPa})$ is the actual vapor pressure calculated from $\mathrm{Td}(\mathrm{oC})$, which is the mean daily dew point temperature. For a complete explanation of the equation, see Allen et al. (1998). Calculated values of reference evapotranspiration (ETo) were 643 and $647 \mathrm{~mm}$ in 2006 and 2007, respectively.

\section{Actual evapotranspiration (ETc)}

The actual evapotranspiration ETc was measured using gravimetric soil samples on $15 \mathrm{~cm}$ intervals down to $60 \mathrm{~cm}$ were taken at sowing and before and two days after every irrigation as well as at harvest time to determine the ETC of maize crop according to Israelsen and Hansen (1962), using the following formula:

$$
E T_{C}=D x B d\left(Q_{2}-Q_{1}\right) 100
$$

Where:

$E T_{C}$ : actual evapotranspiration $(\mathrm{mm})$,

$D$ : $\quad$ soil depth $(\mathrm{cm})$,

$B_{d}$ : bulk density $\left(\mathrm{g} . \mathrm{cm}^{-3}\right)$,

$Q_{1}$ : $\quad$ soil moisture (\%) before next irrigation,

$Q_{2}$ : $\quad$ soil moisture (\%) 48 hours after irrigation

The ETc values were 553, 410 and $293 \mathrm{~mm}$ for treatments A, B and C respectively. Because the fields were small, distribution uniformity, application efficiency and storage efficiency were not determined.

\section{Yield and Water Productivity}

A $7 \mathrm{~m} \times 10 \mathrm{~m}$ area was harvested from the center of each plot, the ears were shelled, and the grains were weighed and adjusted to $15.5 \%$ moisture content to obtain the grain yield $\left(G_{y}\right)$ in $\mathrm{kg} \mathrm{ha}^{-1}$. Water productivity $\left(W_{P}\right)$ was calculated from using the $A_{W}\left(\mathrm{~m}^{3} \mathrm{ha}^{-1}\right)$ following Talha and Aziz (1979) as:

$$
W_{p .}=\frac{G_{y}}{A_{w}}
$$


Ten ears, which were randomly chosen from each plot, were kept in sunny dry place until fully dried. The dried corn ears were used to estimate the number of ears plant ${ }^{-1}$, ear length $(\mathrm{cm})$, ear diameter $(\mathrm{cm})$, ear weight $(\mathrm{g})$ and 100-kernel weight $(\mathrm{g})$.

\section{Economical Analysis}

Price inputs and outputs were calculated for the various irrigation methods. The cost of irrigation for the different methods was calculated based on rental of a water pump $(7.7 \mathrm{Hp})$ that is discharging at $75 \mathrm{~m}^{3} \mathrm{hr}^{-1}$ at a cost of one hour pumping 1.0 \$(EGP 5) $\mathrm{hr}^{-1}$ by calculating the irrigation costs as:

$$
C_{i .}=\frac{C_{t}}{G_{y}}
$$

Where $C_{i}$ is the cost of irrigation $\left(\$\right.$ ton $\left.^{-1}\right), C_{t}$ is the total cost of irrigation in whole season, and $G_{y}$ is the grain yield (ton ha ${ }^{-1}$ ). The economic efficiency for capital investment $\left(\eta_{e}\right)$ was computed as:

$$
\eta_{e}=\frac{\text { Net profit }}{\text { Total outlay }} \times 100
$$

The investment ratio (\$ per \$) was calculated as:

$$
\frac{\text { Total price return }}{\text { Total outlay }}
$$

\section{RESULTS AND DISCUSSION}

\section{Water Saving and Actual Evapotranspiration}

This study tested three planting methods effect on maize yield and water saving as a function of applied water. The mean of applied water $\left(A_{W}\right)$ was determined over two seasons (Table 2) with the highest $A_{W}(814 \mathrm{~mm})$ observed for the traditional method (A). Treatment $\mathrm{B}$ had $30.3 \%$ and treatment C $53.2 \%$ less $A_{W}$ relative to treatment (A). The seasonal actual evapotranspiration was measured; the data in Table (2) show that the consumptive water use for the treatment (B) was decreased by $26 \%(410$ $\mathrm{mm})$ and for treatment $\mathrm{C}$ was decreased by $47 \%(293 \mathrm{~mm})$ as compared with the traditional method $(553 \mathrm{~mm})$. This decrease indicates that the 
new method decreased the evaporation loss because of shading the wet soil under the plants in the furrows. The need to apply water to sub-up water to the ridges was less for the new method which led to decreased percolation loss. This new approach could improve the overall irrigation efficiency without any water stress on the corn plants. Several investigators have studied the optimal seasonal applied water and water consumptive use for irrigated corn using the traditional method (treatment A) in the soil at the same region of Egypt, and they found that the applied water was $900 \mathrm{~mm}$ (Gondium 1985), $1064 \mathrm{~mm}$ (Eid, et al, 1988), $970 \mathrm{~mm}$ (EL-Nagger et al. 1996), $790 \mathrm{~mm}$ (El Refaie and Khater 1996), $888 \mathrm{~mm}$ (Khedr et al, 1996) and $842 \mathrm{~mm}$ (Abou El-Azem et al. 2000). For water consumptive use it was $688 \mathrm{~mm}$ (Eid, et al, 1988), $540 \mathrm{~mm}$ (Abou ElAzem et al. 2000), $547 \mathrm{~mm}$ (Abdel-Aziz et al, 2004) and $637 \mathrm{~mm}$ (ElGarhi et al, 2007). Generally this study clearly showed that applied water can be greatly reduced using the new planting and irrigation method without an adverse effect on production.

The higher irrigation requirement for treatment $\mathrm{A}$ is likely due to the need to wet the furrows sufficiently long to sub-up water to maize planted on the beds. Also, treatments $\mathrm{B}$ and $\mathrm{C}$ had plants growing directly in the wetted furrows, which are partially shaded from direct sunlight. This might have reduced soil evaporation. The wetted surface area of treatment $\mathrm{C}$ was less than for treatment A by $50 \%$.

\section{Yield and Its Components}

Analysis of variance during the two growth seasons indicated that irrigation methods had significant influence on all yield components with the exception of ear diameter (Table 3). The highest mean values for plant height and ear height were recorded for treatment $\mathrm{C}$. The differences between $\mathrm{A}$ and $\mathrm{B}$ treatments were insignificant. For ear length and number of ears plant ${ }^{-1}$ were significantly affected by the irrigation and planting method. While the highest mean values for ear diameter, ear weight, and 100-kernel weight were recorded for treatment $\mathrm{C}$ followed by treatment $\mathrm{B}$. The differences between $\mathrm{B}$ and $\mathrm{C}$ were insignificant, but both $\mathrm{B}$ and $\mathrm{C}$ treatments had significantly higher values than treatment $\mathrm{A}$. 
Table (3): Effect of irrigation method on growth characteristics and yield components of corn; based on the results from two growing seasons. ${ }^{1}$

\begin{tabular}{|c|c|c|c|c|c|c|c|}
\hline Trts & & & & & plt & & \\
\hline A & & & & & & & \\
\hline & & & & & & & \\
\hline & & & & & & & \\
\hline \multicolumn{8}{|c|}{$\begin{array}{l}\text { e same letter indicates no statistical difference between treatments based on } \\
\text { can's multiple range test. } \\
\text { a in Table (2) show that grain yield was significantly affected by } \\
\text { nting methods when averaged over both seasons. Relative to treatment } \\
\text { grain yield was significantly higher for treatment B }(6 \%) \text { and for } \\
\text { atment C ( } 9 \% \text { ). This increase could be partially due to increased } \\
\text { ilizer efficiency; since fertilizer was applied in the bottom of the } \\
\text { ows whereas plants were grown in two rows in bottom of furrows } \\
35 \mathrm{~m} \text { width) with } 1.25 \mathrm{~m} \text { between furrows. With this wide distance } \\
\text { ween furrows, better utilization of sunlight was also likely. Recall that } \\
\text { tment B had one row of plants in each furrow with } 0.8 \mathrm{~m} \text { between } \\
\text { s. Treatment A had } 0.8 \mathrm{~m} \text { between rows, but with the rows planted on } \\
\text { ridges. The treatment C plants were bigger and seemed more } \\
\text { orous, so they probably had better use of fertilizer and light. In } \\
\text { tment C, the wider row spacing also facilitated cultural practices. }\end{array}$} \\
\hline
\end{tabular}

\section{Water Productivity}

Among the three treatments, treatment $\mathrm{C}$ had the highest water productivity $\left(1.73 \mathrm{~kg} \mathrm{~m}^{-3}\right)$ followed by treatment $\mathrm{B}\left(1.13 \mathrm{~kg} \mathrm{~m}^{-3}\right)$. Treatment A had the lowest value $0.74 \mathrm{~kg} \mathrm{~m}^{-3}$ (Table 2). The relative increases in water productivity over the traditional irrigation were $52.7 \%$ and $133.8 \%$ for treatments B and C, respectively. The very high increase in water productivity for treatment $\mathrm{C}$ because of the large reduction in applied water and small increase in grain yield.

Generally-based on the high water saving with higher production hence higher water productivity, it seems that planting corn in the bottom of the furrows, where the water is applied, permitted better distribution of irrigation water around the roots and maintained the soil moisture content 
closer to the optimum level. Both treatments B and C had better utilization of irrigation water and nutrients. Excess wetting of the furrows to sub-up water to the ridges may have resulted in greater leaching of nutrients from around root zone and possibly bad aeration due to excessive irrigation to the clay soil which has negative impacts on both crop growth and yield.

\section{Economical Evaluation}

Traditional planting of maize (on the ridge) (treatment A) required considerably more applied water than when the crop was seeded into the furrows (treatments $\mathrm{B}$ and $\mathrm{C}$ ). When the corn was planted to the bottom of the furrows (treatments $\mathrm{B}$ and $\mathrm{C}$ ), less pumping time was required as shown in Table (2). The total irrigation duration for treatment $\mathrm{C}$ is half $\left(50.8 \mathrm{hr} \mathrm{ha}^{-1}\right)$ of its value for treatment $\mathrm{A}\left(108.6 \mathrm{hr} \mathrm{ha}^{-1}\right)$ because it was unnecessary to sub-up to wet the soil on the ridges. Reducing the irrigation durations means reducing the pumping costs and irrigation labour costs consequently the net profit was increased. This is clear in Table (4) which indicates that treatment $\mathrm{C}$ gave the best economical return for the investment followed by treatment $\mathrm{B}$. Comparing the treatment $\mathrm{A}$, the net profit increment was $19 \%$ and $32 \%$ for treatment $\mathrm{B}$ and $\mathrm{C}$, respectively. The higher economical return resulted from a combination of higher production and less applied water.

Table (4): Inputs and outputs for a corn crop under different irrigation methods as the mean of two seasons.

\begin{tabular}{|c|c|c|c|c|c|}
\hline \multirow{2}{*}{$\begin{array}{l}\text { Econ. } \\
\text { items }\end{array}$} & \multirow{2}{*}{ Characters } & \multicolumn{4}{|c|}{ Planting methods } \\
\hline & & Unit & $\mathbf{A}$ & B & C \\
\hline \multirow{8}{*}{ 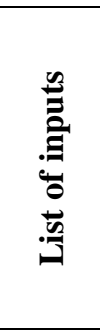 } & Land preparation and cultivation & $\$ /$ ha & 40.00 & 40.00 & 40.00 \\
\hline & Seed price & $\$ /$ ha & 29.84 & 29.84 & 29.84 \\
\hline & Mineral fertilizers & $\$ /$ ha & 105.24 & 105.24 & 105.24 \\
\hline & Pest control & $\$ /$ ha & 11.90 & 11.90 & 11.90 \\
\hline & Labor costs & $\$ /$ ha & 31.75 & 31.75 & 19.84 \\
\hline & Cost of irrigation in whole season & $\$ /$ ha & 127.65 & 90.60 & 64.40 \\
\hline & Harvesting & $\$ /$ ha & 30.00 & 30.00 & 30.00 \\
\hline & Land rent & $\$ /$ ha & 622.00 & 622.00 & 622.00 \\
\hline \multirow{8}{*}{ 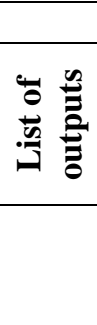 } & Total cost/ha/season & \$/ha & 998.38 & 961.33 & 923.22 \\
\hline & Grain yield & $\mathrm{kg} / \mathrm{ha}$ & 6067.00 & 6400.00 & 6600.00 \\
\hline & Price & $\$ / \mathrm{kg}$ & 0.28 & 0.28 & 0.28 \\
\hline & Total Price & $\$ /$ ha & 1698.00 & 1792.00 & 1848.00 \\
\hline & Net Profit & \$/ha & 699.62 & 830.67 & 924.94 \\
\hline & Cost of irrigation/ton & $\$$ & 21.04 & 14.16 & 9.76 \\
\hline & Economic efficiency for capital & $\%$ & 70.16 & 86.44 & 100.20 \\
\hline & Investment ratio & $\$ / \$$ & 1.70 & 1.86 & 2.00 \\
\hline
\end{tabular}




\section{CONCLUSION}

Seeds planted in the bottom of furrows rather than on the ridges increased water saving by about $30.3 \%$ when compared with the traditional method having the same planting density and the distance $(0.8 \mathrm{~m})$ between rows. The in-furrow planting increased yield by $6 \%$ over the traditional method. Planting seeds in two rows in the bottom of each furrow with $1.25 \mathrm{~m}$ between furrows and the same planting density as the traditional planting having $0.8 \mathrm{~m}$ between rows, led to $53.2 \%$ water savings. This in-furrow planting increased the yield by $9 \%$ over the traditional planting. It is hypothesized that the better performance resulted from less need to apply water to sub-up water to the ridges, which led to decreased percolation loss. Shading of wet soil under the plants in the furrows also likely decreased soil surface evaporation. Since the irrigation requirement was reduced, the costs for pumping and labor were reduced. This is a new farm management and planting technique, further detailed studies on soilplant-water relationships and irrigation efficiencies are needed to be emphasized.

\section{ACKNOWLEDGMENTS}

This work was financially and technically supported by the Water Management Research Institute (WMRI) of Egypt. The authors would like to thank Prof. Dr. Nahla Abou El-Fotouh, the Director of WMRI and Prof. Dr. Fathy El-Gamal, the former Director of WMRI and all staff of Zankalon Water Research Station at Sharkia, Egypt for their support.

\section{REFERENCES}

Abdel-Aziz, A.; El-Set U. and S. El-Bialy (2004) "Response of maize plant to soil moisture stress and foliar spray with potassium." J. Agric. Sci. Mansoura Univ., 29 (6): 3599-3619.

Abou El-Azem, A.; Atta Y. I. and Meleha M. (2000) "Effect of skipping irrigation at different plant growth stages of corn on yield, consumptive use and water use efficiency." Egypt J. of Appl. Sci., 15 (4), $152-165$. 
Ahmad R., A. Mahmood; M. Ikraam and B. Hassan (2002) "Influence of different irrigation methods and band placement of nitrogen on maize productivity." Int'l J. of Agric. \& Biology, 5608530/2002/04-4-540-543.

Allen, R. G.; Pereira, L. S.; Raes, D. and Smith, M. (1998) "Crop evapotranspiration guidelines for computing crop water requirements." FAO Irrigation and Drainage Paper No. 56, United Nations-Food and Agricultural Organization, Rome, Italy, 300 p.

Bakker, D. M.; S. R. Raine and M. J. Robertson (1997) "A preliminary investigation of alternate furrow irrigation for sugar cane production." Conference of the Australian Society of Sugar Cane Technologists, Cairns, Queensland, 29 ${ }^{\text {th }}$ April to $2^{\text {nd }}$ May 1997, pp. 302-309.

Donahue, R. L.; Miller R. W. and Shickluna J. C. (1977) "Soils: An introduction to soils and plant growth. Prentice. Hall. Inc. Englewood Cliffs.” New Jeresy $076324^{\text {th }}$ edition pp. 383-393.

Eid, H.; M. Ibrahim and N. G. Ainar (1988) "Controlled irrigation for field crops production with the context of improved farming systems." Minya Conference of Field irrigation and Agrometeorology, 20-23 June.

El-Garhi, I. A.; M. K. Matter; N. G. Ainar and N. N. Sidrak (2007) "Irrigation scheduling of corn ((Zea mays L.) in Middle Egypt." Zag. J. Agric. Res., Vol. 34 No. (3): 501-512.

El-Naggar, L. M.; El-Awag T. I. and Hanna A. M. (1996) "Production of some field crops as influenced by water regime and potassium application.” Egypt. J. of Appl. Sci., 11(9), 211 - 225.

El-Refaie, M. M. and Khater A. N. (1996) "Effect of irrigation systems and quantities of water applied on yield and water relations of corn.” Egypt. J. of Appl. Sci., 11(4), 329- 343.

Fischbach, P.E. and H.R. Mulliner (1974) "Every-other furrow irrigation of corn'. Trans. ASAE, 17: 426-8. 
Gondium, L. A. (1985) "Timing of irrigation for corn (Zea mays L.) on meadow soils in Rio Grende do sul. Lavoure Arrozeira." 38 (362) 14, 16 -18 (C.F). Corn Abst (1986) 2 (5), 298.

Kanga, S., Z. Liang; Y. Pan; P. Shi and J. Zhang (2000) "Alternate furrow irrigation for maize production in an arid area." Agric. Water Management J. Vol. 45, Issue 3, pp 267-274.

Kemper, W.D.; W. Clyma, R. Ali and G. Haider (1975) "Water management and nitrogen fertilizer movement and utilization in soils”. Annual Progress Report. Water Management Res. Project. CSU, Fort Collins. USA.

Khedr, E. A.; M. Samia and G. M. Mahgoub (1995) "Response of some maize varieties to irrigation intervals" Egypt. J. of Appl. Sci., 10(5), 30- 44.

Mahal, S.S.; D.G. Dejenu and M.S. Gill (2000) "Growth and yield of maize (Zea mays L.) as influenced by flood under different planting methods and nitrogen levels". Env. Ecology, 18: 789-92 (CAB Absts., 2000.

Mintesinot, B.; H. Verplancke; E. Van Ranst and H. Mitiku (2004) "Examining traditional irrigation methods, irrigation scheduling and alternate furrows irrigation on Vertisols in Northern Ethiopia" Agric. Water Management J., Vol. 64, Issue 1, pp 17-27.

Mitchell, A.R.; Shock C.C. and Perry, G.M. (1995) "Alternatingfurrow irrigation to minimize nitrate leaching to groundwater". Conference Proc. 'Clean Water-Clean Environment- $21^{\text {st }}$ Century', March 1995, Kansas City, Missouri, ASAE.

Selvaraju, R. and M.R. Iruthayaraj (1993) "Effect of irrigation scheduling, methods of irrigation and nitrogen levels on growth analysis parameters of maize". Madras Agric. J., 80: 562-5.

Steel, R. G. and Torrie J. M. (1980) "Principles and procedures of statistics." Second ed. Mc. Grow Hill Co. New York. USA. 
Stone, J. F. and Nofziger, D.L. (1993) "Water use and yields of cotton grown under wide-spaced furrow irrigation". Agric. Water Man. 24 (1): $27-38$.

Talha, M. and Aziz M. A. (1979) "Effect of irrigation and fertilization on yield and water economy of potato plant.” Egypt J. of Soil Sci., $19(2), 231-243$

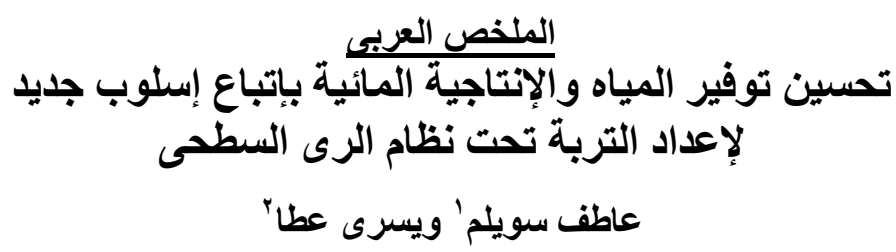

نم إجراء التجارب فى محطة البحوث المائية التابعة لمعهد بحوث إدارة المياه وطرق الرى بالي

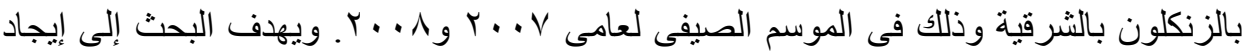

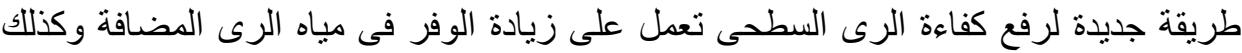

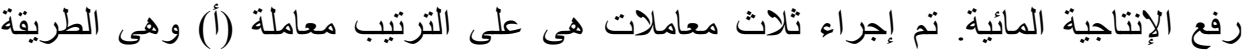

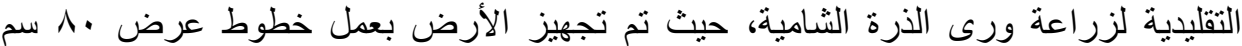
وزر اعة صف واحد من نباتات الذرة على الريشة العليا للخط و المسافة بين الجور بـ بـ سم ونبات

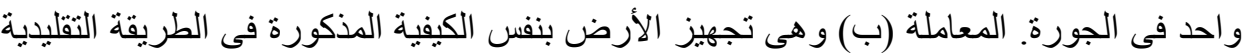

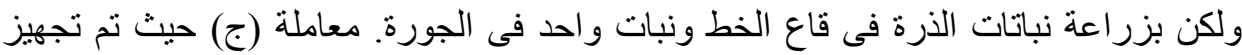

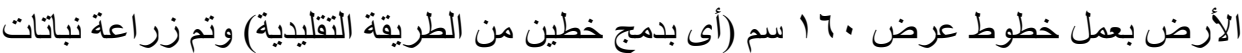

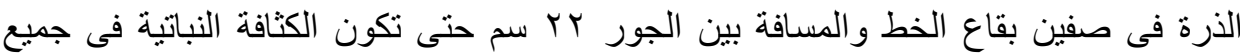

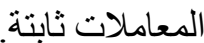

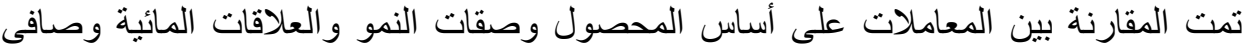

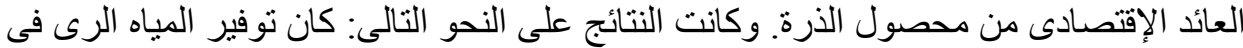

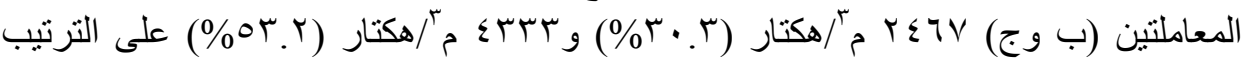

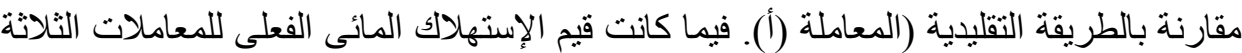

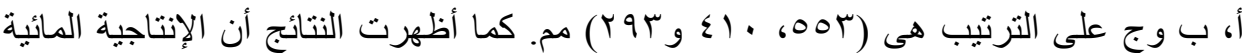

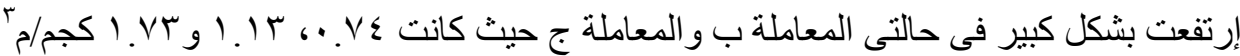

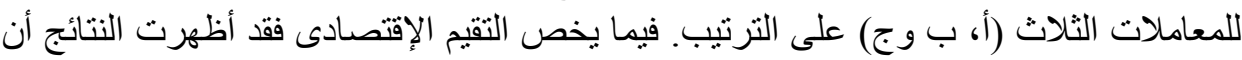
أقل تكاليف إنتاج كانت تحت إستخدام المعاملة (ج).

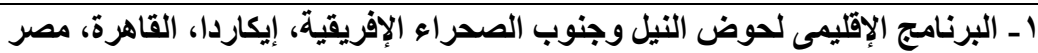

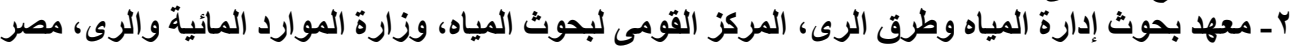




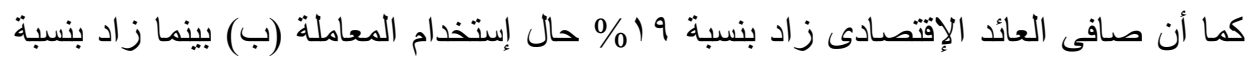

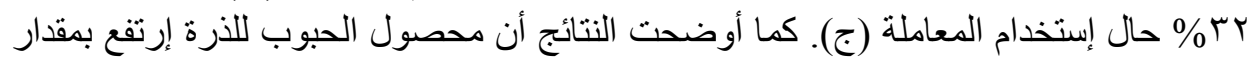

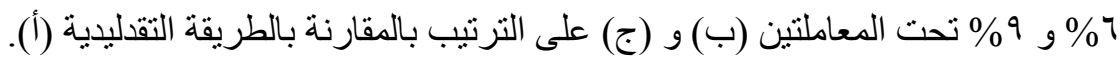

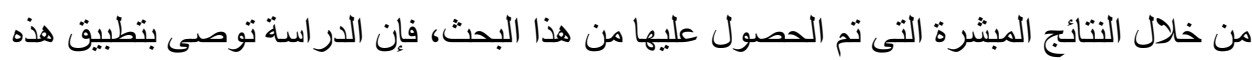

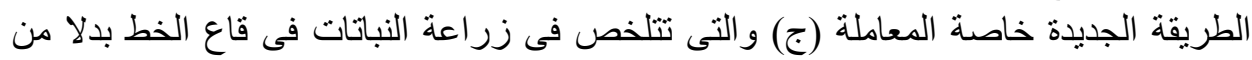

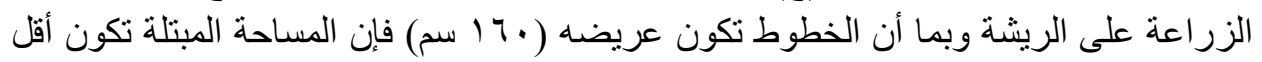

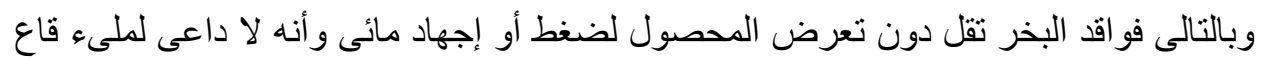

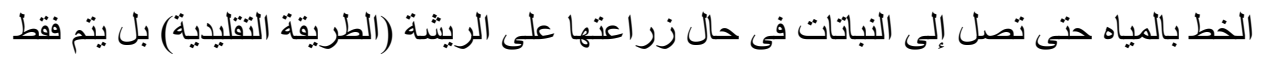

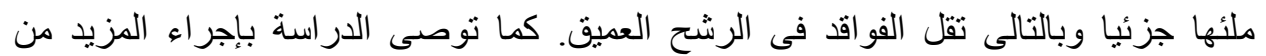

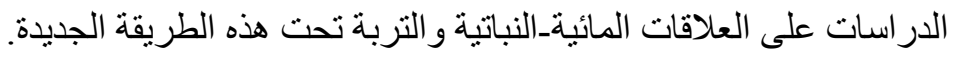

